\title{
CDISC SDTM ECG Test Code Terminology
}

National Cancer Institute

\section{Source}

National Cancer Institute. CDISC SDTM ECG Test Code Terminology. NCI Thesaurus.

Code C71153.

Terminology codelist used with ECG Tests within the Clinical Data Interchange Standards Consortium Study Data Tabulation Model. 